\title{
МУТАЦІЙНО-ІНМУТАЦІЙНІ НАСЛІДКИ ВПЛИВУ РЕКЛАМИ НА ДІТЕЙ І ПІДЛІТКІВ
}

\begin{abstract}
Статтю присвячено теоретичному аналізу вітчизняних і зарубіжних досліджень впливу реклами на дитячу і підліткову цільову аудиторію. Наголошено, що діти і підлітки є найбільш незахищеними цільовими групами, на які мова реклами, маніпулятивна у своїй основі, впливає особливо сильно, спричинюючи найбільші первинні і вторинні мутаційно-інмутаційні ефекти. Увагу зосереджено на визначенні впливу реклами в контексті метатеорії маніпуляції О. М. Холода, зокрема мутаційних та інмутаційних наслідків впливу реклами. Проаналізовано власне психологічні особливості маніпулятивного впливу реклами на дітей і підлітків. Вплив реклами розглянуто під кутом зору його наслідків: як мутаційний (якщо він зумовлює зміну моделі світогляду і поведінки на краще), як абмутаційний (якщо таких змін не відбувається) і як інмутаційний (у разі зміни світогляду і моделі поведінки на гірше). У зв'язку із соціальною значущістю досліджуваної проблеми основну увагу зосереджено на стадійності впливу реклами на дітей і підлітків, зокрема на змінах у свідомості, які спричинює реклама, а також змінах, що відбуваються в поведінці. 3'ясовано, що: рекламний вплив стимулює у дітей та підлітків інтерес до рекламної продукції; інтерес як мотив спонукає до практичної дії та зумовлює зміни у звичній поведінці; наслідками маніпулятивного впливу реклами на дітей через повідомленнянавіювання можуть бути інмутаційні або мутаційні зміни; за умови ж ігнорування змісту рекламного повідомлення, недостатнього бажання діяти чи браку дієвих засобів для змін вони можуть і не відбуватися (абмутація). Встановлено, що 3-поміж усіх інших цільових груп споживачів рекламної продукції діти є групою потенційного, а підлітки - групою підвищеного ризику. Визначено, що вплив реклами на цільову аудиторію дітей і підлітків слід розглядати як матракаж, що провокує інмутаційні зміни поведінки, результатом яких є соціальна мімікрія. Особливу увагу приділено інмутаційним наслідкам впливу реклами на дітей і підлітків: деформації їхньої мотиваційно-потребової сфери, формуванню негативного іміджу, появі схильності до конформізму, ідеалізації віртуального світу, когнітивному дисонансу, стереотипності мислення і поведінки, підлітковому нігілізму, соціальній мімікрії.

Ключові слова: реклама, матракаж, мутація, абмутація, інмутація, соціальна мімікрія.
\end{abstract}

Постановка проблеми. Реклама є невід'ємною частиною сучасного життя. “Мовою переконування” реклама щодня апелює до нашої свідомості і підсвідомості, намагаючись у той чи інший спосіб переконати нас діяти певним чином на користь заздалегідь прийнятих за нас рішень. Рекламні меседжі на кшталт “Дій!..”, “Купуй!..”, “Будь!..”, “Обирай!..”, “Роби вибір!..” і т. ін. сприймаються як належне, адже є 
зрозумілими і переконливими для всіх цільових аудиторій, яким вони адресовані. Це, зокрема, пояснюється тим, що сучасна реклама враховує психологічні особливості всіх вікових груп (цільових клієнтів рекламного маркетингу).

Звернімо увагу на той факт, що цільові аудиторії різні, проте мова, якою реклама звертається до них, завжди однакова. Це мова психологічного переконування, під впливом якої цільові клієнти рекламного маркетингу роблять “вибір без вибору", у той чи інший спосіб роблять так, як роблять усі. Саме тому кожна людина має замислюватися над тим, який вибір вона робить - “вибір без вибору”, або псевдосвідомий вибір, без усвідомлення того, хто і за допомогою чого стимулює іiї прагнення діяти. Порушене питання стосується медіакомпетентності споживачів рекламної продукції. Наразі воно є досить актуальним, адже розуміння мови реклами визначає міру іiі впливу на споживачів рекламної продукції. Мусимо визнати, що сьогодні тільки медіаграмотна частина цільових клієнтів рекламного маркетингу розуміє, що "мова реклами" $є$ штучно створеною і маніпулятивною у своїй основі. При цьому завдяки достатньому рівню медіаграмотності такі люди здатні контролювати міру впливу реклами. Для тих, у кого низький рівень медіаграмотності, реклама є звичайним джерелом інформації, яка впливає на них щодня, щогодини з теле- і радіоканалів, журналів, газет, інтернет-мережі, листівок у громадському транспорті, біг-бордів тощо.

Вплив реклами на споживачів рекламної продукції $\epsilon$ незаперечним. Сьогодні, в умовах інформаційного тиску і рекламного матракажу, доцільно ставити питання про розуміння наслідків маніпулятивного впливу реклами, насамперед наслідків впливу реклами на найменш захищені групи населення, якими є діти і підлітки. Отже, дослідження мутаційно-інмутаційних наслідків впливу реклами на дітей і підлітків $\epsilon$ актуальним предметом сучасних психолого-педагогічних досліджень.

Аналіз останніх досліджень $i$ публікаиій. Ірунтовні науковоприкладні дослідження в галузі психології реклами розпочалися на рубежі XIX-XX століть. На особливу увагу серед них заслуговує творчий доробок У. Д. Скотта, який визнав, що мова рекламних оголошень $\epsilon$ маніпулятивною, спрямованою на споживачів, які легко піддаються сугестивному впливу (див. [4]). На початку XXI ст. дослідження впливу реклами на різні цільові групи набуло нового характеру в контексті метатеорії маніпуляції суспільством, автором якої є О. М. Холод. Його методологеми мали інноваційний характер, адже він започаткував аналіз процесів маніпулювання в межах метатеорії маніпуляції суспільством [5].

Сучасна психологія реклами як галузь наукових знань перебуває в постійному розвитку, адже рекламна діяльність інтенсивно змінюється та розвивається. Науковці досліджують рекламу, рекламну діяльність як системне явище, завдяки чому їі почали розглядати як: форму масової 
комунікації (Ж.-Ж. Ламбен, Р. Харріс, Ч. Сендідж, Ст. Фрайбургер, В. В. Ученова, Н. В. Старих, Е. В. Ромат); неперсоніфіковане передавання інформації шляхом переконування споживача продукції (К. Бове, У. Аренс); неособисту комунікацію, що використовується засобами масової інформації задля переконування або впливу (Дж. Бернет, М. Моріарті); непряме переконування за рахунок емоційної привабливості того, що рекламується (Д. Росситер, Л. Персі).

Одним із перспективних напрямів досліджень у галузі психології реклами $є$ дослідження впливу реклами на різні цільові групи клієнтів рекламного маркетингу. Такі дослідження проводяться в напрямах: з'ясування мотивів впливу, що використовуються в рекламі (Л. М. Хромов); аналізу процесів маніпулювання в межах метатеорії маніпуляції суспільством (О. М. Холод, Т. О. Клінкова, Н. Г. Кравченко, Є. С. Цимбаленко); визначення наслідків впливу реклами залежно від вікових особливостей клієнтів (Ю. А. Асєєв, Н. О. Ярош); впливу реклами на дітей (О. Г. Асмолов, Н. Є. Березовська, Л. У. Звонарьова, Н. В. Колесникова); характеристики впливу реклами на школярів молодшого віку (Ю. В. Василькіна, Б. С. Волков, Л. Звонарьов); впливу реклами на підлітків (Н. М. Авдєєва, Н. О. Фоміних, О. М. Нікітіна, Л. Г. Сокурянська, М. Діас).

Невирішені раніше частини загальної проблеми. Незважаючи на наявність достатньої кількості наукових робот з проблеми впливу реклами на цільових клієнтів рекламного маркетингу, мусимо визнати, що не всі іiі аспекти висвітлені повною мірою. Недостатньо дослідженими залишаються первинні і вторинні мутаційно-інмутаційні ефекти впливу реклами на дітей і підлітків, а саме деформації, які виникають на когнітивному, мотиваційно-потребовому і поведінковому рівнях.

Meта cmammi: теоретичний аналіз мутаційно-інмутаційних наслідків впливу реклами на цільові групи дітей і підлітків.

Виклад основного матеріалу дослідження. Намагаючись проаналізувати в контексті метатеорії маніпуляції наслідки маніпулятивного впливу реклами на цільові групи клієнтів рекламного маркетингу, а саме дітей і підлітків, насамперед визначимо, що таке реклама, який вплив вона має на цільові групи. Серед останніх виокремимо "групу ризику" - тих, кому вплив реклами потенційно загрожує інмутаціями світогляду і поведінки.

Словом "реклама" найчастіше позначають діяльність 3 виробництва рекламної продукції, а також самі продукти цієї діяльності. У “Сучасному словнику іншомовних слів" реклама (від фр. reclame, лат. reclamo - вигукую, кличу) тлумачиться як: 1) популяризація чогось за допомогою преси, радіо, телебачення, плакатів тощо; 2) поширення інформації про що-небудь або кого-небудь; 3) засіб привертання уваги покупців, споживачів, глядачів, користувачів тощо [3, с. 588]. Слід розу- 
міти, що інтерпретація терміна "реклама" залежить від контексту, в якому він використовується: як синонім терміна "рекламна діяльність" (у широкому сенсі); як вид рекламної діяльності (поряд з пропагандою, саморекламою та іншими маркетинговими комунікаціями); як оголошення в газетах, як телевізійний ролик, як рекламний плакат тощо. Така ситуація спричинюється до термінологічної невизначеності, унаслідок чого в кожному конкретному випадку розуміння лексичного значення слова “реклама" має визначатися в контексті його використання.

Аналогічна неузгодженість існує і в поглядах науковців щодо класифікації видів реклами. Критеріями класифікації видів реклами зазвичай стають: цільові аудиторії (споживча і ділова реклама); функції і цілі (товарна, корпоративна, нетоварна реклама); сфери поширення рекламної продукції (зарубіжна, загальнонаціональна, регіональна, місцева, внутрішньофірмова); засоби передавання реклами (телевізійна, радіореклама, друкарська, транспортна, сувенірна, поліграфічна, поштова, комп'ютерна); способи уявлення (візуальна реклама). Виділяють вісім видів реклами, що відрізняються метою рекламного впливу (далі по тексту - МРВ): 1) реклама конкретної торгової марки (МРВ - упізнавання бренду і торгової марки); 2) роздрібно-торговельна реклама (МРВ стимулювання продажів шляхом залучення покупців до конкретної торгової точки або підприємства); 3) корпоративна реклама (МРВ переконування певного сегмента покупців зайняти позицію компанії); 4) довідково-адресна реклама (МРВ - надання інформації відразу декільком групам споживачів); 5) реклама 3 наявністю зворотного зв'язку (МРВ - обмін інформацією з потенційними покупцями); 6) політична реклама (МРВ - формування позитивного іміджу); 7) бізнес-реклама (МРВ - поширення рекламних повідомлень серед груп населення, об’єднаних за загальними ознаками); 8) соціальна реклама (МРВ вплив на цільову аудиторію, об'єднану за соціальними ознаками: діти, підлітки, пенсіонери і т. ін.) [1].

Аналогічна ситуація методологічної невизначеності склалася наразі і довкола поняття “вплив” (рекламний вплив). Загальновідомо, що вплив реклами грунтується на силі навіювання, що впливає на психіку людини. Завдяки технології навіювання він знижує рівень свідомого контролю та критичності мислення в момент сприймання змісту рекламного повідомлення, унаслідок чого воно сприймається більшістю людей як таке, що не потребує логічного аналізу і критичної оцінки. Зауважимо, що вплив виступає одночасно і як процес, і результат. Як процес, вплив постає як дія або сукупність дій, спрямованих на зміну об'єкта впливу (це дія, спрямована на зміну потребово-мотиваційного комплексу об'єкта рекламного впливу). Як результат, вплив набуває конкретних форм, а саме дій, що змінюють поведінку. Отже, впливаючи за допомогою мови маніпуляції на різні цільові групи 
клієнтів рекламного маркетингу, реклама, що апелює до їхніх емоцій, змінює тим самим їхню поведінку.

Емоційні реакції на вплив реклами різні. Вони характеризуються такими полярними ознаками, як: “задоволення - невдоволення"; “збудження - заспокоєння"; “напруженість - розслаблення". Так, відомо, що задоволення або невдоволення пов'язані з відчуттям смаку, запаху, болю. Стан збудження або заспокоєння виникає під впливом певних кольорів та звуків. Напруженість або розслаблення безпосередньо пов'язані 3 процесами уваги: зокрема, брак інформації викликає негативні емоції, а наявність повної і об'єктивної інформації - позитивні. Усе це враховується в ході створення рекламної продукції. Намагаючись переконати цільових клієнтів купити або зробити щось, рекламодавці, які добре знаються на "мові переконування", використовують спеціальні методи і практики, за допомогою яких “умовляють” або відверто переконують нас діяти певним чином. Формулу впливу реклами можна представити так: “увага - інтерес - бажання - дія”. Реклама привертає увагу, викликає інтерес, об’єктивує бажання і мотивує дію споживача рекламної продукції. Вплив реклами характеризується стадійністю від змін на рівні внутрішньої психічної діяльності, зокрема свідомості, до змін у зовнішній практичній діяльності, насамперед поведінці. Отже, рекламний вплив стимулює інтерес до рекламованої продукції, а інтерес як мотив спонукає до дії (від дії мисленнєвої до дії практичної), зумовлюючи в такий спосіб зміни у звичній поведінці. Відповідно, ці зміни $є$ наслідками рекламного впливу (маніпулятивного за своїм характером).

Маніпулятивний вплив реклами на людину може мати різні наслідки: мутаційні (зміна моделі світогляду і поведінки під впливом реклами на краще), абмутаційні (коли змін немає), а також інмутаційні (зміна світогляду і моделі поведінки під впливом реклами на гірше). Зосереджуючи увагу на інмутаційних наслідках впливу реклами, зауважимо, що відповідно до метатеорії маніпуляції суспільством О. М. Холода інмутації охоплюють процеси: розбалансування (первинна зміна моделі поведінки); руйнування (значні зміни моделі поведінки); знищення (незворотні зміни в поведінці) (див. [6, с. 8]).

Методи і технології маніпулятивного впливу реклами різні. Так, у рамках проекту медіаграмотності “Мова переконування” було визначено 40 найбільш поширених методів переконування, серед яких на особливу увагу заслуговують 10 методів і практик переконування: асоціативний метод (утілюється в техніках “красиві люди”, “символи”, "ностальгія", “техніка тепла" тощо); метод інтенсивного впливу за допомогою лагідних слів (реалізується через техніку “ласкаві слова”); метод “людина-зірка", або метод “відомих людей”; техніка "простої людини”; метод лестощів; метод “хабарництва”; метод експертних і 
наукових доказів; метод перебільшення (гіперболізації); гумористичний метод [8].

Вищенаведені техніки маніпулятивного впливу реклами на різні цільові групи клієнтів рекламного маркетингу можуть мати різні наслідки. Проаналізуймо їх на основі критеріїв впливу, де ФВ (формула впливу): увага - інтерес - бажання - дія; КК (канали комунікації): прямий непрямий; ПКВ (психологічні компоненти впливу): когнітивний; афективний; регуляторний; комунікативний; МВ (методи впливу): повідомлення; переконування; навіювання (сугестія); НВ (наслідки впливу): МНВ - мутаційні наслідки впливу; АНВ - абмутаційні наслідки впливу; IHB - інмутаційні наслідки.

Діти є цільовою аудиторією рекламного маркетингу. Досвід перших мутаційно-інмутаційних змін під впливом реклами ми набуваємо в дитинстві. Вплив реклами на дитячу цільову аудиторію має свою специфіку. Реклама завжди привертає увагу дітей. Яскрава реклама (особливо телереклама) викликає інтерес у дитячої аудиторії і провокує появу бажання мати саме те, що показують, наслідувати поведінку тих героїв реклами, які викликають симпатію і захоплення. Кінцева мета впливу реклами на дітей, а саме “дія", залежить від батьків. Діти не можуть купити те, що рекламується; щоб отримати бажаний рекламний продукт, вони звертаються до дорослих. Їхні дії (прохання, умовляння i навіть вимагання) зрештою або підтримуються дорослими, або ні. Проте діти не питають дозволу батьків з приводу наслідування тієї чи іншої форми поведінкової реакції, інтонації, міміки тощо. Діти просто копіюють те, що привертає їхню увагу, те, що викликає позитивні емоції і спонукає до наслідування.

Формулу впливу (ФВ) реклами на дітей можна визначити як: увага - інтерес - бажання - опосередкована дія. Намагаючись отримати бажане, діти “дієво" спонукають батьків до відповідних дій. Можна сказати, що реклама на цьому етапі досягає мети, вона створює через прямий канал комунікації (безпосередній вплив) непотрібні потреби i вмотивовує на їх реалізацію через зворотні дії дорослих. Домінантними психологічними компонентами впливу при цьому є афективно-когнітивні компоненти. Рекламний вплив формує потреби, а інтерес як мотив спонукає до дій. Відбуваються інмутації конативного компонента (“Купи!” - умовляння купити через зміни значущих потреб). Якщо дорослі не обмежують вплив реклами, а саме не контролюють того, що, як і якою мірою впливає на дитину, навіювання робить свою справу (відбуваються мутаційно-інмутаційні зміни).

За О. М. Холодом, інмутаційні зміни починаються з розбалансування (початкового процесу змін моделей поведінки) унаслідок дії соціально-комунікаційних технологій, серед яких у контексті дослідження рекламного впливу ми звертаємо увагу на технології: зміни на 
негативне фізіологічних, соціально значущих потреб і потреби соціальної самореалізації особистості; інмутаційно-педагогічні технології формування світогляду; когнітивні технології примусового керування поведінкою; технології прагматизування поведінки, технології бібліотерапії; технології зміни на негативне фізичного стану; технології зміни світогляду (див. [6, с. 8]).

Наслідками маніпулятивного впливу реклами на дітей (через повідомлення-навіювання) можуть бути як інмутаційні (деструктивний вплив на свідомість - споживацька психологія; надмірна мрійливість; хибні уявлення про спосіб життя; поява шкідливих звичок; нехтування правилами здорового харчування; наслідування демонстративних форм поведінки; стереотипність мислення і т. ін.), так і мутаційні зміни. Процес додавання (як початкова стадія мутації під впливом реклами) реалізується завдяки сприйманню позитивної інформації і зміні на іiі основі звичної моделі поведінки на краще (формування емпатії; стимуляція розвитку пізнавальних процесів; реалізація нових просоціальних форм поведінки тощо). Так, соціальна реклама, спрямована на допомогу онкохворим, безпритульним та іншим соціально незахищеним верствам, здатна спонукати дітей до добровільних позитивних змін. Логічно також припустити, що наявність абмутації під впливом реклами такого змісту майже неможлива. Відсутність будь-яких змін під впливом реклами (абмутація) стає можливою лише за умови ігнорування змісту рекламного повідомлення (коли в дітей не виникає бажання і немає засобів для змін) або належного контролю з боку батьків будь-яких інмутаційних впливів реклами на психіку дитини (наявність бажання у дітей, коли при цьому в них немає ресурсів і засобів, які контролюються батьками).

Періодом підвищеної вразливості перед силою навіювання i маніпулювання $\epsilon$ підлітковий вік, особливо молодший підлітковий вік, так званий період початку “другого народження особистості”. Споживачі рекламної продукції молодшого підліткового віку не здатні до критичного сприйняття реклами. Неглибокі знання моральних норм та еталонів поряд 3 іншими віковими особливостями зумовлюють категоричні і безкомпромісні оцінки зовнішнього впливу. На тлі нестійких моральних переконань молодших підлітків рекламні меседжі стають специфічними мотивами поведінки, адже внаслідок слабкої виконавської частини вольового акту підлітків вони дуже легко викликають в останніх емоційні переживання (питання лише в тому, який характер вони мають). Бажане (об'єкт бажання) завжди посилює емоційну напруженість. Зовнішній маніпулятивний вплив реклами посилює бажання, при цьому підліткам важко стримувати ригідно-інертні емоції. Отже, формула впливу $(\Phi В)$ реклами на підлітків виглядатиме як: увага інтерес - бажання - дія. 
Основними психологічними компонентами впливу (ПКВ) щодо підлітків є: афективний, когнітивний, регулятивний. Методи впливу (MB): повідомлення; переконування; навіювання (сугестія) - переконування в психологічному комфорті і захищеності. Зауважимо, що, впливаючи силою навіювання на підлітків, наслідки впливу реклами мають розглядатися як мутаційно-інмутаційні зміни на рівні їхнього світогляду і поведінки. Особливу увагу необхідно приділяти таким інмутаційним наслідкам впливу (НB), як деформація мотиваційнопотребової сфери; формування негативного іміджу; поява схильності до конформізму; ідеалізація віртуального світу; когнітивний дисонанс; стереотипність мислення і поведінки; підлітковий нігілізм, соціальна мімікрія.

У контексті вищенаведеного заслуговують на увагу дослідження М. Діаз, яка, розглядаючи вплив реклами на підлітків, зробила категоричний висновок, що реклама створює непотрібні потреби [7]. Цікавим видається також творчий доробок А. С. Лобанової, яка визначила соціальну мімікрію як специфічний адаптивно-адаптувальний спосіб життєдіяльності, “що полягає в опосередкованості дії, у свідомому намірі людини (групи) вибірково уподібнюватися до навколишнього середовища 3 метою виживання або пристосування через приховування своєї істинної системи ціннісних орієнтацій та справжніх намірів" [2].

Отже, силою навіювання реклама впливає на дітей і підлітків, які $є$ найбільш емоційно чутливими до іiі впливу. Наслідки впливу реклами мають розглядатися в контексті метатеорії маніпуляції як мутаційні або інмутаційні зміни на рівні їхнього світогляду і поведінки. Дорослі мають пильнувати за дітьми, адже щодня діти "отримують" рекламні меседжі про те, що: “час прощатися із їжею, що докучає...”; що щось “... допоможе підтримати гарну форму”; що тільки “...тут все і навіть більше"; про “особливі овочі - особливий смак”; про сік, що “...допоможе підтримати гарну форму”; про те, що “залізні нерви тільки 3 ...”; про те, що шкіра “виглядає ідеальною завдяки ...”; про те, завдяки чому життя може стати солодким (“.... Дивись, яке в мене солодке життя”); про те, що нам треба щось купити, “.... адже ми цього варті”; про те, що, тільки купуючи продукцію ...., ми здатні зробити все і зараз - "Я можу все. Я вирішую ....”, і навіть про те, що “світ традиційно рухається вперед - традиції незмінні”, тощо.

Із приводу останнього рекламного меседжу (з реклами горілчаної продукції) зауважимо, що з огляду на його зміст складається враження, що для дорослої аудиторії горілка іманентна традиціям. Чому ж при цьому ми не замислюємося над тим, що імпліцитний зміст цього рекламного повідомлення може сформувати у дітей (навіть на рівні зорового сприймання) та підлітків (які повною мірою усвідомлюють те, що чують i бачать) ейджизм, негативний стереотип, стосовно того, що споживання 
горілки, виявляється, є справою традиційною, а традиції незмінні? Це лише один приклад, що ілюструє інмутаційний вплив “дорослої” трешіміджевої реклами на дітей і підлітків. Якщо замислитися, наскільки він дієвий для підлітків, які намагаються в будь-який спосіб довести всім, і собі в першу чергу, що вони все можуть, що вони дорослі і самостійні в прийняття рішень, що вони вільні у виборі, то стає зрозумілим, що вплив змісту реклами на дітей і підлітків матиме інмутаційні наслідки у вигляді різноманітних поведінкових девіацій. Зрозуміло, що наявність девіантності і делінквентності засвідчує перебіг проміжного інмутаційного процесу, а саме руйнування (саморуйнування) просоціальних форм поведінки, загальнолюдських морально-етичних ідеалів і норм.

Найбільший вплив діти і підлітки відчувають з боку телереклами. Вплив телереклами на цільову аудиторію дітей і підлітків слід розцінювати як матракаж, який цілеспрямовано впливає на їхню емоційну сферу. Оскільки діти і підлітки є найбільш емоційно чутливими до рекламного впливу, то цей вплив вони відчувають сильніше і звикання до рекламованої продукції (конкретного продукту або моделі конкретної вчинкової дії) відбувається у них швидше. Це провокує різкі зміни настрою і поведінки. Дорослим людям потрібно пам'ятати, що рекламу показують цілий день, а отже, ії вплив, враховуючи ту кількість часу, який діти і підлітки проводять біля телеекранів і комп'ютерів, набуває характеру матракажу. Матракаж є своєрідною “емоційною обробкою”, після якої діти і підлітки починають неусвідомлено наслідувати запропонований їм стиль поведінки, переймають і повторюють певні фрази 3 рекламних роликів, наслідуючи голосову міміку, мову інтонацій і жестів, не розуміючи при цьому, що тим самим вони втрачають свою індивідуальність, стають одним із тих, хто під сугестивним впливом реклами робить "вибір без вибору".

Висновки. В умовах інформаційного суспільства реклама стає могутнім засобом впливу на дітей і підлітків, який здатен змінювати їхній світогляд і поведінку. Діти і підлітки - найбільш незахищені цільові групи, у яких мова реклами, маніпулятивна у своїй основі, викликає найбільші первинні і вторинні мутаційно-інмутаційні ефекти. Останні мають стати предметом подальших наукових досліджень, спрямованих на аналіз ефектів впливу реклами, зокрема таких, як негативні зміни фізіологічних і соціально значущих потреб дітей і підлітків під дією інформаційно-комунікаційних технологій.

\section{Лimepamypa}

1. Данилко В. О. Класифікація видів реклами / В. О. Данилко, Л. С. Рибалко // Науково-дослідна робота студентів як чинник удосконалення професійної підготовки майбутнього вчителя : зб. наук. праць. - Харків : Віровець А. П. “Апостроф”, 2012. - Вип. 6. - С. 50-52. 
2. Лобанова А. С. Соціальна мімікрія як адаптивний спосіб життєдіяльності : автореф. дис. на здобуття наук. ступеня д-ра соціол. наук : спец. 22.00 .04 “Спеціальні та галузеві соціології” / А. С. Лобанова. - Київ, 2005. - 36 с.

3. Нечволод Л. І. Сучасний словник іншомовних слів / Л. І. Нечволод. Харків : Торсінг плюс, 2008. - 768 с.

4. Резепов И. Ш. Психология рекламы и PR / И. Ш. Резепов. - Москва : Дашков и Ко, 2009. - 224 с.

5. Холод О. М. Інмутаційні, абмутаційні та мутаційні процеси сучасного суспільства в межах метатеорії маніпуляції / О. М. Холод // Світ соціальних комунікацій. - Київ, 2012. - Т. 8. - С. 7-10.

6. Цимбаленко $\epsilon$. Інмутація під впливом рекламних повідомлень / Є. Цимбаленко // Світ соціальних комунікацій. - Київ, 2012. - Т. 8. - С. 118-121.

7. Alcantud D. M. Manipulation of teenagers through advertising: a critical discourse approach. Revista de Lingüística y Lenguas Aplicadas, [S. 1]. - (Oct.) [Electronic resourse] / Alcantud Diaz Maria. - 2011. - Vol. 6. - P. 25-38. Access mode : https://polipapers.upv.es/index.php/rdlyla/article/view/879/936.

8. Prelipceanu C.-M. Advertising and language manipulation [Electronic resourse] / Cristina-Maria Prelipceanu. - Access mode : http://www.diacronia. ro/ro/indexing/details/A3999/pdf.

\section{References}

1. Danylko, V. O., \& Rybalko, L. S. (2012). Klasyfikatsiia vydiv reklamy [Classification of types of advertising]. Naukovo-doslidna robota studentiv yak chynnyk udoskonalennia profesiinoi pidhotovky maibutnoho vchytelia [Research work of students as a factor for improving the professional training of the future teacher], 6, 50-52 (ukr).

2. Lobanova, A. S. (2005). Sotsialna mimikriia yak adaptyvnyi sposib zhyttiediialnosti. Abstract of D. Sc. Dissertation, Institute of Sociology NAS Ukraine, Kyiv (ukr).

3. Nechvolod, L. I. (2008). Suchasnyi slovnyk inshomovnykh sliv [The modern dictionary of foreign words]. Kharkiv: Torsinh plius (ukr).

4. Rezepov, I. Sh. (2009). Psikhologiya reklamy i PR [Psychology of advertising and PR]. Moscow: Dashkov i Ko (rus).

5. Kholod, O. M. (2012). Inmutatsiini, abmutatsiini ta mutatsiini protsesy suchasnoho suspilstva v mezhakh metateorii manipuliatsii [Inmutational, abmutational and mutational processes of modern society within the framework of the metatheory of manipulation]. Svit sotsialnykh komunikatsii [The World of Social Communications], 8, 7-10 (ukr).

6. Tsymbalenko, Ye. (2012). Inmutatsiia pid vplyvom reklamnykh povidomlen [Immutation under the influence of advertising messages]. Svit sotsialnykh komunikatsii [The World of Social Communications], 8, 118-121 (ukr).

7. Alcantud, D. M. (Oct. 2011). Manipulation of teenagers through advertising: a critical discourse approach. Revista de Lingüística y Lenguas Aplicadas, [S. 1], vol. 6, pp. 25-38, https://polipapers.upv.es/index.php/rdlyla/article/view/879/936.

8. Prelipceanu, C.-M. Advertising and language manipulation, http://www.diacronia. ro/ro/indexing/details/A3999/pdf. 


\section{Shcherbakova I. M. Mutational-and-Inmutational Consequences of the Influence of Advertising on Children and Adolescents}

The article is dedicated to theoretical analysis of national and foreign surveys on the advertising impact on the target audience of children and adolescents. Children and teenagers are the most vulnerable target groups in which the language of advertising, manipulative in its essence, is particularly influential and causes the greatest primary and secondary mutational-and-inmutational effects. Attention is focused on determination of the influence of advertising in the context of the metatheory of manipulation by $\mathrm{O}$. Kholod, in particular mutational and inmutational consequences of advertising influence. It is analysed in the article psychological peculiarities of manipulative influence of advertising on the target audience of children and adolescents. The impact of advertising is considered as mutational (it causes a change in the outlook and behaviour model under the influence of advertising for the better), abmutational (no change), inmutational (change of outlook and behaviour model under the influence of advertising for the worse). Due to the social significance of the studied problem, the emphasis is focused on the staging of advertising influence on children and adolescents, in particular on changes in consciousness caused by advertising and changes of behaviour. It was found out that advertising influence stimulates interest of children and teenagers to advertised production. Interest as a motive induces practical action and causes changes of usual behaviour. Inmutational or mutational changes can be consequences of manipulative impact of advertising on children due to the message suggestion. The lack of any changes under the influence of advertising (abmutation) is possible under the condition of ignoring of content of the advertising message, lack of desire to act or lack of effective means for changes. It is established that children make a group of potential risk, and adolescents are a group of increased risk among another target groups of consumers of promotional products. It is determined that the influence of advertising on the target audience of children and adolescents should be considered as a matrakazh, which mainly provokes the inmutational changes of behaviour, the result of which is a social mimicry. Special attention needs to be paid to inmutational consequences of influence of advertising on children and teenagers: to deformation of motivating needs; to formation of negative image; to appearance of tendency to conformism; to idealization of the virtual world; to a cognitive dissonance; to stereotyped thinking and behaviour; to teenage nihilism, to social mimicry.

Key words: advertising, matrakazh, mutation, abmutation, inmutation, social mimicry.

(C) Щербакова I. M. 